\title{
POSSIBILITIES FOR THE DEVELOPMENT OF RURAL TOURISM IN THE REPUBLIC OF MACEDONIA
}

\author{
Cane Koteski, ${ }^{1}$ Darko Majhošev, ${ }^{2}$ Zlatko Jakovljev ${ }^{3}$ \\ ${ }^{1,2,3}$ Faculty of Tourism and Business Logistics, \\ University "Goce Delchev" - Štip, Macedonia \\ cane.koteski@ugd.edu.mk; darko.majhosev@gmail.com; zlatko.jakovlev@ugd.edu.mk
}

\begin{abstract}
Rural tourism as part of the overall tourist offer in Macedonia is currently booming. Almost every tourist offer of all the travel agencies contains, among other things, visiting interesting rural tourist areas. This kind of tourism is an important alternative form of tourism that offers a higher level of meeting modern man's needs that urban lifestyle is not able to satisfy. The dynamic and stressful life in urban areas contributes to people seeking peaceful areas that are far from urban centers which, with their natural potentials, offer the modern and somewhat tired man quality contents for relaxing and resting. These are rural areas that are identified with certain geographical regions possessing natural beauty, historic sights and cultural events that are an important factor for the development and promotion of rural tourism. Modern entrepreneurs perceive rural tourism as economic development of rural areas which brings significant revenues for families dealing with this kind of tourism, and also as a significant factor in keeping the population in these rural areas. The paper contains conceptual determination and definition of rural tourism, rural tourism types, and retains the profile of rural tourism visitors. The second part of the paper analyzes the situation with rural tourism in Macedonia, especially the legal framework for the development of rural tourism, institutional framework, human resources, accommodation and catering facilities, funding opportunities, promotional activities, etc.
\end{abstract}

Key words: relaxation and recreation, rural environment, rural development, economic potential.

\section{Concept and definition of tourism}

To explain the essence of rural tourism we will first define the concept of tourism. There are several definitions of the term tourism, however, for us the most acceptable one is that "tourism is traveling for fun, pleasure, seeing interesting regions, treatment etc." ${ }^{1}$ Etymologically the word tourism (tour) has its roots in several similar words in different languages (Lat. "tornare", Gr. "tornos", Fr. "tour") which means circle, moving around a point or axis.

According to Jafari "Tourism is the study of people who travel outside their place of residence, the industry that meets their needs and the impact that people and industry have on the socio-cultural, economic and physical environment of the host" ${ }^{\prime 2}$.

According Matheison and Wall, "Tourism is the temporary movement of people out of their permanent residence and place of work and it covers the actions performed during their stay, and in facilities built to meet their needs". ${ }^{3}$

\footnotetext{
1 Vujaklija, M., (1980), Leksikon stranih reci i izraza, Prosveta, Beograd, str. 938.

2 Jafari, J., "Annals of Tourism Research" V (Special Number, October/December) 8, 1977

${ }^{3}$ Matheison, A., \&Wall, D., "Tourism: Economic, physical and social impacts", Longman Group Ltd, London, 1982
} 
According to the World Tourism Organization, "Tourism comprises the activities of persons traveling to and staying in places outside their usual environment for not more than one consecutive year for leisure, business and other purposes not associated with the exercise of an activity remunerated from within the place visited"1.

From all the above mentioned definitions of tourism we can draw one common feature and it is that tourism is related to "persons traveling from their permanent place of residence" .

\section{Concept and definition of rural tourism}

In the mid-60s of the last century rural tourism was synonymous with "cheap tourism", 6 because it was much cheaper compared to the standard mass tourism. In Japan this kind of tourism is called "slow tourism" because it is the opposite of "fast life in cities". ${ }^{7}$ Rural tourism is typical for people who live in highly urbanized countries, wishing to return to the primordial needs of a man in nature and natural beauty, while not spending a lot of financial resources, and discovering unknown crafts, specific cuisine, and new cultures. ${ }^{8}$ This kind of tourism is usually related to offering capabilities such as "peace and quiet", "landscape and nature", "walks", "health and fresh air," "isolation from the urban chaos," "seeing domestic

\footnotetext{
${ }^{4}$ WTO, Concepts, definitions and classifications for tourism statistics-A Technical Manual, Item 3, Madrid, 1995 p. 21.

5 Metodijeski, D., (2012), "Turizmot vo ruralnite sredini", Sovremenost, Skopje, str. 20.

${ }^{6}$ Metodijeski, D., (2012), "Turizmot vo ruralnite sredini", Sovremenost, Skopje, str. 25.

${ }^{7}$ Penerliev, M., "Selski turizam-satojanie, problem i tendencii",prezemeno od Metodijeski, D., "Turizmot vo ruralnite sredini", Sovremenost, Skopje, str. 39.

8 Jaworski, A., "Discourse, communication and tourism", Channel View Publication, (pdf), p. 129.
}

animals", "acquaintance with local specialties" and other.

This type of tourism should be developed as a family business and only as such can it meet the above expectations of guests. The essence of rural tourism is the result of its typical features comprising: the environment in which tourism is realized (a settlement in the rural area), accommodation facilities are typical for rural areas and an opportunity for a holiday (active and passive). In combination with other types and forms of tourism (wine, mountain, ecotourism), rural tourism offers a complex product that is interesting and attractive for tourists from large urban areas.

\section{Types of rural tourism}

Many authors equate rural tourism with farming and agritourism, others distinguish them. Holland, Dixey and Burian explain rural tourism as farming or agritourism, but these two are sub-categories of tourism in rural areas. ${ }^{9}$ Agritourism is when the purpose of the visit has a specific focus on agriculture, contact with farm animals or on a visit to a vineyard, while farming tourism is when rural tourists are accommodated on farms. Besides the above mentioned, rural tourism also covers camp parks, safari tours, craft markets, cultural exhibitions, adventure sports, hiking trails, sites of historical heritage, music events, etc.

Agritourism is a term associated with agriculture, including traditions and customs a tourist meets with. It refers to various activities closely connected with agriculture work, such as: production of vegetables, pomiculture, stockbreeding and facilities required to carry out business activity.

\footnotetext{
${ }^{9}$ Holland, J., Dixey, Л., Burian, M., "Tourism in poor rural areas: diversifying the product and expanding the benefits in rural Uganda and Czech Republic", PPT, N.12, 2003 (pdf).
} 
An important factor for agritourism is the production element, i.e. the production activity of the family as a source of revenue. Agritourism is developed in Italy.

Farming tourism as a subtype of rural tourism is a term usually identified with connecting to a farm. Tourists stay on the farm where they work, and are accommodated in farmhouses which are adjacent to the farm. In Austria, France, Germany, Slovenia and other countries there are farms for leisure and these farms for a holiday are a combination of agriculture and tourism.

\section{Profile of rural tourists}

Organizations dealing with rural tourism should take into account what kind of guests they want to attract, i.e. what their profile is. The selection should be based on realistic predictions and characteristics such as age, income, interests, family structure, home location, mobility, etc. This requires a systematic study of the rural tourism market.

Day-visitors. This kind of visitors is an important segment in the overall development of rural tourism, especially those living in urban areas which are adjacent to the rural ones. Good infrastructure and transportation links are a good potential and an incentive to visit interesting rural destinations.

Visitors on a short holiday. Lately a lot of visitors prefer short visits (holiday) that lasts a few days, usually during the weekend 3-4 days and they visit the less accessible regions in Europe. This tendency is also present in Macedonia.

Families. It is a tendency in Europe for families to rest for a few days, most often on the farms that have good and safe accommodation. But for the families that love this kind of tourism the cost of service and the content of the arrangement are important factors.

Elderly visitors. Rural destinations are popular among older groups that enjoy both rural traditions and customs and tranquility. Generally, this population requires a higher standard of comfort.

Special Interest Tourists. This group includes people who have specific interests such as walking, hiking, biking, local heritage, folklore, gastronomy, etc.

Educational groups. Rural areas are also interesting in relation to the educational needs of citizens in urban areas. Many rural areas are interesting for group visits, such as school groups. Visits are connected with themes from rural life which are related to: agriculture, cultural heritage, folklore events, conservation, etc.

\section{Analysis of the conditions in rural tourism in Macedonia}

\subsection{Legal framework for the development of rural tourism}

From the analysis of the provisions of the Law on Tourism and the Law on Catering it can be concluded that a precise definition of the scope of the term rural tourism is needed, in accordance with the standards of the World Tourism Organization, as well as the expansion of the scope of tourism services offered in rural tourism.

According to the Law on Tourism Article 51 services for rural, ethnic and ecotourism are provided by a physical person, which is not consistent with the concept of creating small businesses in rural tourism and stimulating the development of this branch. These shortcomings in the Law on Tourism generate an array of inconsistencies and ambiguities for service providers in rural tourism. 
Simultaneously, standards for tourist accommodation services in rural tourism are regulated in the Law on Catering, which leads to the conclusion that there is no legal act that precisely regulates and defines the standards and terms covering rural tourism despite general compliance of national legislation with EU legislation. Also, there are no by-laws (regulations) that regulate the field of technical conditions, in particular the categorization according to EUROGITES (European Federation of Rural Tourism) and the standards for rural tourism. The existing regulations define the general classification and the minimum technical requirements of tourist facilities - renting houses that are categorized by getting an appropriate number of stars.

\subsection{Institutional facilities for developing rural tourism}

In the Republic of Macedonia there are several institutions that are important for the development of tourism or rural tourism. At the state level we would emphasize the following:

Ministry of Economy - Department of Tourism and Catering, Agency for Promotion and Support of Tourism, Ministry of Agriculture, Forestry and Water Management - Department of Rural Development. Within the Government there is a Committee on Tourism which is formed with the purpose of coordination and effective implementation of the part of the government program for the development of tourism.

Pursuant to the legal regulations on territorial division, the Republic of Macedonia consists of eight regional planning regions. All eight regions in the country have institutional Region centers within which the regional tourism development should be planned and implemented through designating strategies and action plans for development.

At the level of local government units (municipalities) there are Departments of Local economic development with sectors and departments for tourism.

The institutional capacity includes Associations of citizens and groups for tourism and catering at the Chambers of Commerce. All listed institutions have an important role in tourism development, including rural tourism.

\subsection{Human resources}

Although by its nature rural tourism implies engagement of people from one family, this branch cannot experience growth without the involvement of professional staff to provide a quality product. Marketing activities, formation of a service package, establishment of pricing policies, following the trends and needs of potential guests, testing and continuous improvement of products - all these require highly specialized staff in the areas of marketing and finance.

Currently, in the educational system of $\mathrm{RM}$ there are no forms of training of informal education that provide training for individuals or groups interested in practicing activities related to rural tourism. Hence there is a need for knowledge of standards in hospitality, knowledge of languages (depending on the selected segment of guests), knowledge of the history and culture of the region and other knowledge and skills for which there are currently no training nor defined criteria. 


\subsection{Accommodation and catering facilities}

According to the methodology for recording accommodation and catering facilities, there is no record of accommodation and catering facilities offering services in rural tourism as a separate category. The situation with the total accommodation capacity shows a tendency of growth throughout the Republic of Macedonia with the imbalance at the level of growth of respective regions.

When separating the accommodation facilities in exclusively rural municipalities, estimates show that in 2009 in Macedonia only $3.7 \%$ of the total catering facilities with accommodation were in strictly rural areas and they have only $1.15 \%$ of the total number of beds in the Republic of Macedonia. ${ }^{10}$

The situation in catering facilities without accommodation is more optimistic in rural areas. The number of seats in the catering facilities in rural areas accounts for $15.4 \%$ of the total number of seats in the catering facilities in the country.

Based on the latest data from the SSO about the overnight stays spent in facilities ending with 2010 it can be assumed that tourists who spent nights in some private accommodation, camps, and other uncategorized objects are actually tourists who belong to Rural Tourism in Macedonia

\subsection{Funding opportunities}

For the development of rural tourism in Macedonia the instrument of the European Union Pre-Accession Assistance Rural Development - IPARD (2007-2013) is

\footnotetext{
${ }^{10}$ National strategy for rural tourism 2012-2017, Ministry of Economy, Department of Tourism, p. 27
}

very important. With this instrument the EU and the national budget provide financial support (co-finance) the investment in rural tourism, in particular:

1) For reconstruction of the agricultural economy facilities intended for rural tourism, together with recreational facilities;

2) For building catering facilities, outdoor accommodation (camping sites), recreational facilities and

3) For modernization and renovation of old crafts. The National Rural Development Program provides a measure of co-financing of local roads with a maximum length of $2 \mathrm{~km}$ which will contribute to linking rural settlements in order to develop all rural activities. A very important segment of the development of rural tourism in the country is certainly Government funding by subsidizing the tour operators and travel agencies for the stay of foreign guests in rural areas.

\subsection{Promotion activities}

In 2008, the Republic of Macedonia established the Agency for Promotion and Support of Tourism. Starting from 2008, the Republic of Macedonia made a serious step forward with the campaign "Macedonia Timeless" in the international promotion of the country as a unique tourist story. Within the campaign eight thematic videos were made covering all aspects of the best of the Macedonian tourist offer. The promotion of natural, cultural, authentic gastronomic and tourist offer of Macedonia in a number of most influential world media is especially important for rural tourism. Significant progress has been made in the field of the Internet promotional tools and social networks where the most important tourist information on the opportunities and offer as well as on rural tourism in the country can be found. 
Macedonia currently has two national promotional web portals "Macedonia Timeless" and "Exploring Macedonia". The TV project - Exploring Macedonia as an educational and promotional campaign has significantly contributed to understanding the peculiarities and characteristics of rural areas and authentic tourism products for the rural tourism in the country. Nevertheless, it is necessary to improve the promotional activities for rural tourism in foreign countries by preparing special tour guides for the opportunities of rural areas in the country.

\section{Conclusion}

Rural tourism is a type of tourism that has great potential. It can, in certain regions, extend the tourist season, which will increase the number of employees in this sector. To achieve this, besides the development of infrastructure, the following is necessary:

1) To improve the skills of the human potential, primarily:

a) creating a staff to manage rural tourism which will be able to develop and promote rural tourism. It is also necessary to educate staff that will know how to develop a project, to write the project documentation in order to apply for obtaining financial resources from $\mathrm{EU}$ funds and from national funds

b) improving employees' skills in this sector that are of a personal nature and refer to raising the level of presentation skills and active knowledge of several foreign languages ${ }^{11}$, so that the person is able to promote national values in the domain of national cuisine, historical, cultural and religious heritage, stimulating

\footnotetext{
11 National strategy for rural tourism 2012-2017, Ministry of Economy, Department of Tourism, p. 77
}

the development of handicrafts and crafts. $^{12}$

c) in order to stimulate the development of the two previously mentioned skills the establishment of training centers for the development of tourism and hospitality is required.

2) The improvement of communication among institutions at national, regional and local level those are responsible for the development and promotion of tourism is necessary. It requires creating sectors and employment of persons in charge of tourism in regional centers and a specialized sector to support rural tourism in the Agency for Promotion and Support of Tourism in Macedonia.

3) An amendment to article 51 of the Law on Tourism is needed in the part about expanding and full defining of the concept of services for accommodation in rural tourism. Furthermore, it is necessary to amend Article 51 of the Law on Tourism, which stipulates that services can be provided only by a physical person, not by legal entities.

4) The clusters in the region should take measures to connect the capacities of the region with those in the neighboring countries.

5) Easy access to affordable credit lines for individuals and companies that want to invest in facilities in abandoned villages in Macedonia.

6) Renewal of infrastructure and roads that gravitate towards rural areas with major development opportunities.

\footnotetext{
12 National strategy for rural tourism 2012-2017, Ministry of Economy, Department of Tourism, p. 53
} 
7) Local governments together with the Centres for Development of Planning Regions should initiate proceedings for the protection of geographical origin of food, i.e. digitize cultural, historical and religious heritage and attach these on the Internet platforms, which will be promotional tools for potential visitors.

8) In order to enhance the promotion of rural tourism in the Republic of Macedonia abroad, it is necessary that the state budget subsidizes tourism operators to take part at specialized tourism fairs.

\section{References}

[1] Holland, J., Dixey, L., Burian, M., (2003) pdf, "Tourism in poor rural areas: diversifying the product and expanding the benefits in rural Uganda and Czech Republic", PPT, N.12.

[2] Metodijeski, D., (2012), "Turizmot vo ruralnite sredini", Sovremenost, Skopje.

[3] Penerliev, M., "Selski turizam-satojanie, problem i tendencii",prezemeno od Metodijeski, D., "Turizmot vo ruralnite sredini", Sovremenost, Skopje.

[4] Vujaklija, M., (1980), Leksikon stranih reci i izraza, Prosveta, Beograd.

[5] Jafari, J., "Annals of Tourism Research" V (Special Number, October/December) 8, 1977;

[6] WTO, Concepts, definitions and classifications for tourism statistics-A Technical Manual", Item 3, Madrid, 1995

[7] Jaworski, A., "Discourse, communication and tourism", Channel View Publication, (pdf), p. 129.

[8] Nacionalna strategija za ruralen turizam 2012-2017 godina, Ministerstvo za ekonomija, Sektor za turizam, Skopje.

[9] Zakon za turisticka dejnost, Sluzben vesnik na RM br. 62/2004,89/2008,12/2009, 17/2011, 47/2011, 53/2011, 123/2012, 164/2013, 27/2014, 116/15 и 192/15)

[10]Zakon za ugostitelska dejnost, Sluzben vesnik na RM br. 62/04, 89.08, 115/10,
53/11, 141/12, 164/13, 187/13 ,166/14, $199 / 14,129 / 15,192 / 15,39 / 16$ и 71/16)

[11] Matheison, A., \&Wall, D., "Tourism: Economic, physical and social impacts", Longman Group Ltd, London, 1982 